\title{
Records of two species of felines in Oaxaca, México
}

\author{
Helxine Fuentes-Moreno ${ }^{1 *}$, Aida Trejo-Ortiz ${ }^{2}$ and Antonio Santos-Moreno ${ }^{3}$ \\ ${ }^{1}$ Compañía Minera Cuzcatlán, km 42.5 carretera Oaxaca-Puerto Ángel, San José del Progreso CP. 71250, Ocotlán. Oaxaca, México. \\ Email: hfuentes@mincuzcatlan.com (HFM). \\ ${ }^{2}$ Investigador independiente, Iturbide 11 CP. 71256, San Bartolo Coyotepec. Oaxaca, México. Email: aida.trejoortiz@gmail.com (ATO). \\ ${ }^{3}$ Laboratorio de Ecología Animal, Centro Interdisciplinario de Investigación para el Desarrollo Integral Regional, Unidad Oaxaca, \\ Instituto Politécnico Nacional, Hornos 1003, Colonia La Noche Buena CP. 71230, Santa Cruz Xoxocotlán. Oaxaca, México. Email: \\ asantosm90@hotmail.com (ASM). \\ *Corresponding author
}

The State of Oaxaca is home to six felid species. There are regions, such as in the Valles Centrales, where there is no evidence of their presence. This scientific note records two feline species listed in the Norma Oficial Mexicana 059. Two species of felines were recorded in the municipalities of San José del Progreso and San Pedro Totolapan. The photographs are deposited in the Colección de Fotocolectas Biológicas at UNAM (IBUNAM-CFB), plus one specimen in the Colección Nacional de Mamíferos, UNAM. Historical records were sought in the literature and databases. The species were determined based on literature descriptions, collection vouchers, and assisted by expert opinions. The first two records refer to Herpailurus yagouaroundi in oak forest and tropical deciduous forest in San José del Progreso and San Pedro Totolapan. The third is Leopardus wiedii, in a pine forest in San José del Progreso. Herpailurus yagouaroundi has been recorded on the Pacific and Gulf of Mexico slopes. The specimen closest to the ones reported here is located at $63.5 \mathrm{~km}$ from San José del Progreso and $76 \mathrm{~km}$ from San Pedro Totolapan. Leopardus wiedii has been spotted to the north, south and east of the state. The record that is closest to the one of San José del Progreso is located $48 \mathrm{~km}$ to the north. These records contribute to the knowledge of the Valles Centrales of Oaxaca.

En el estado de Oaxaca se distribuyen seis especies de felinos. Existen regiones como en los Valles Centrales, en las que no se cuenta con evidencia de su presencia. Esta nota científica registra dos especies de felinos incluidos en la Norma Oficial Mexicana 059. Se registran dos especies de felinos en los municipios de San José del Progreso y San Pedro Totolapan. Las fotografías se encuentran en la Colección de Fotocolectas Biológicas, UNAM (IBUNAM-CFB) y un ejemplar en la Colección Nacional de Mamíferos, UNAM. Se buscaron registros históricos en bibliografía y bases de datos. Para la determinación de las especies se revisó bibliografía, ejemplares de colección y se contó con la opinión de expertos. Los dos primeros registros son de Herpailurus yagouaroundi en bosque de encino y selva baja caducifolia en San José del Progreso y San Pedro Totolapan. El tercero es un Leopardus wiedii, en bosque de pino en San José del Progreso. Herpailurus yagouaroundi se ha registrado en las vertientes del Pacífico y del Golfo de México. El más cercano a los reportados aquí se ubica a 63.5 km de San José del Progreso y 76 km de San Pedro Totolapan. Leopardus wiedii ha sido registrado al norte, sur y este del estado. El más cercano al de San José del Progreso se encuentra a $48 \mathrm{~km}$ al norte. Estos registros contribuyen al conocimiento de los Valles Centrales de Oaxaca.

Key words: dry forest; Herpailurus yagouaroundi; Leopardus wiedii; oak forest; pine forest; Valles Centrales of Oaxaca.

C 2018 Asociación Mexicana de Mastozoología, www.mastozoologiamexicana.org

\section{Introduction}

Mexico has documented the presence of six species of felines (Villa and Cervantes 2003), all with records in the State of Oaxaca (Briones-Salas and Sánchez-Cordero, 2004; Santos-Moreno 2014; Briones-Salas et al. 2016). However, there are regions within the State where there is no documented evidence of their presence. One example regards the districts of Ocotlán de Morelos and Tlacolula, both in the region of the Valles Centrales. Ocotlán de Morelos, despite its location just $30 \mathrm{~km}$ south of the city of Oaxaca and with an area of $857.9 \mathrm{~km}^{2}$, is characterized by a remarkable lack of information on wild mammals. Thus, from a collection of 17,670 georeferenced and confirmed records of wild mammals of Oaxaca deposited in scientific collections, only four corresponded to the whole District. The Tlacolula District spreads across 3,324.14 $\mathrm{km}^{2}$, with records for 33 mammal species (Monroy-Garcia 2009).

This note contributes to the knowledge of the geographical range of felines in the State of Oaxaca, specifically in the region of the Valles Centrales. This is crucial, as the two species recorded, namely the onza or jaguarundi (Herpailurus yagouaroundi) and the margay (Leopardus wiedii; ÁlvarezCastañeda and Gonzalez-Ruiz 2018) are listed in the Norma Oficial Mexicana 059 (SEMARNAT 2010), under the category of Threatened and Endangered species, respectively, and in Appendix II of the Convention on International Trade in Endangered Species of Wild Fauna and Flora (CITES; www. cites.org).

\section{Materials and Methods}

$H$. yagouaroundi and $L$. wiedii were recorded through photographs and one specimen preserved as skin and skeleton. Photographs were provided by private individuals and are deposited in the Colección de Fotocolectas Biológicas at Universidad Nacional Autónoma de México (UNAM; IBUNAM-CFB). The jaguarundi was donated by private individuals and was deposited in the Colección Nacional de Mamíferos (CNMA) at Instituto de Biología, UNAM. Besides, the VertNet (www.vertnet.org/index.html) and CONABIO (www.gob.mx/Conabio) databases were reviewed, as well as the monograph of mammals of Oaxaca (Goodwin 1969) and recent publications, in search of records of both spe- 
cies for the State (Briones-Salas and Sánchez-Cordero, 2004; Santos-Moreno 2014; Briones-Salas et al. 2016). The determination of the specimen and the identification of photographs were based on Hall (1981), Aranda (2012); also, identifications were supported by comparison with reference specimens deposited at CNMA, and by expert opinions.

\section{Results}

The first record corresponds to one jaguarundi found on 11 May 2013 at 18:00 hrs at "Latajo", 3.7 km south of La Garzona $\left(16.64^{\circ} \mathrm{N},-96.64^{\circ} \mathrm{W}, 2,362\right.$ masl), municipality of San José del Progreso (IBUNAM-CFB-38860). The local vegetation is oak forest (Figure 1a). The second jaguarundi specimen is a female, which was found dead on 3 December 2015, $1.6 \mathrm{~km}$ $\mathrm{NE}$ to El Chacal $\left(16.69^{\circ} \mathrm{N},-96.12^{\circ} \mathrm{W}, 1,141\right.$ masl), municipality of San Pedro Totolapan. The local vegetation is tropical deciduous forest. The somatic measures of the specimen, in millimeters, are: total length 675; vertebral tail 295, right hind leg 114, and ear 40; its weight was $1,000 \mathrm{~g}$ (CNMA 47966). This species displays two color phases, red and gray (Reid 1997); both specimens recorded were gray in color. The third record corresponds to a margay male, found on 24 March 2016 at 15:00 hrs at "El Hueco de la Hiesca", 4.7 km SSE of La Garzona $\left(16.63^{\circ} \mathrm{N},-96.62^{\circ} \mathrm{W}, 2,153\right.$ masl), municipality of San José del Progreso (IBUNAM-CFB-38861). The local vegetation is pine forest (Figure $1 \mathrm{~b}$ ).

\section{Discussion and Conclusions}

The jaguarundi is considered as a common species in Oaxaca (Goodwin 1969). However, only 12 individuals have been recorded on the Pacific and Gulf of Mexico slopes. The most recent records have expanded its distribution range to the northwest of the State (Briones-Salas and SánchezCordero, 2004; CONABIO 2010a; Briones-Salas et al. 2016) and to the Tehuacán-Cuicatlán Biosphere Reserve (Botello et al. 2013). The record closest to those described in this work is located to the south, in San Miguel Suchixtepec (CONABIO 2010a), at $63.5 \mathrm{~km}$ from San José del Progreso and $76 \mathrm{~km}$ from San Pedro Totolapan (Figure 2).

Two subspecies of margay have been historically recorded in Oaxaca: L. wiedii oaxacensis, which inhabits the upper parts of the center of the state, and L. W. yucatanica,

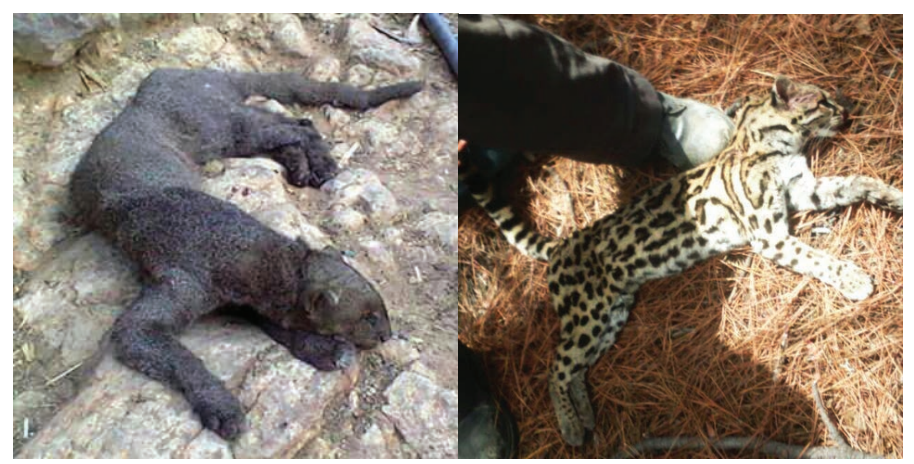

Figure 1. Photographs of the specimens registered in the Municipality of San José del Progreso, Oaxaca, Mexico, a) onza or jaguarundi (Herpailurus yagouaroundi). b) margay (Leopardus wiedii).

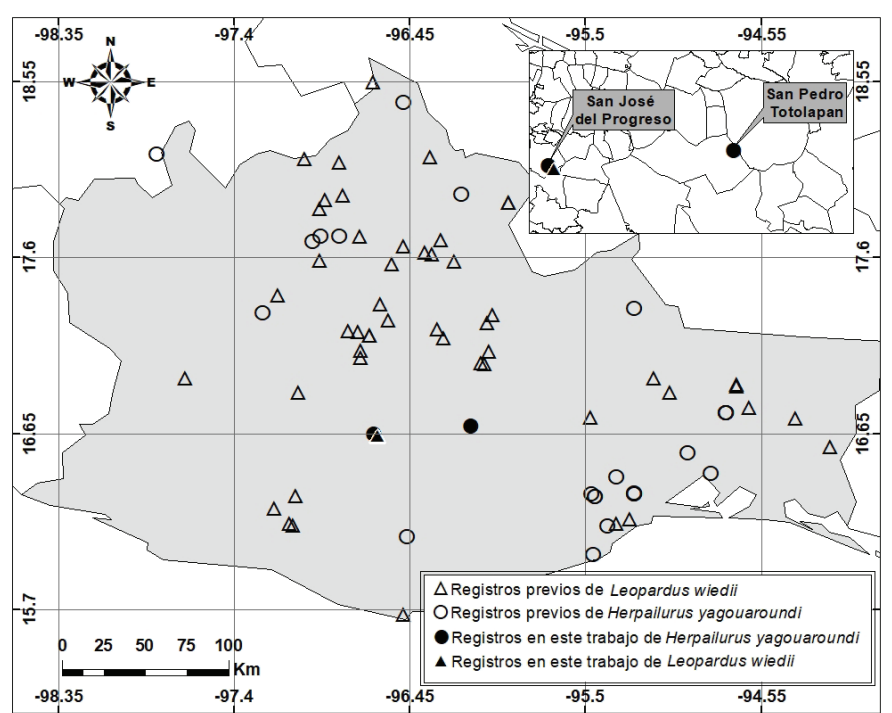

Figure 2. Records of onza or jaguarundi (Herpailurus yagouaroundi) and margay (Leopardus wiedii) in Oaxaca, Mexico

distributed toward the Isthmus of Tehuantepec in the arid tropical region (Goodwin 1969). Subsequent works have documented their presence to the north of the State, in temperate humid and semiwarm climates: mountain cloud forests, pine forests, and oak forests (Cinta 2007; Perez 2008; CONABIO 2010b; Cinta-Magallon et al. 2012), and in the coastal region (Meraz et al. 2010). The margay in tropical deciduous forest in Oaxaca was first recorded in the Tehuacán-Cuicatlán Biosphere Reserve (Botello et al. 2006).

Only five records belong to the center of the state of Oaxaca, located in the districts Centro (Goodwin 1969; CONABIO 2010b), Etla (CONABIO 2010b), and Mixe, where the presence of margay was recorded from footprints in a pine forest (Lavariega et al. 2012). The record closest to the one of San José del Progreso, district of Ocotlán de Morelos, is located $48 \mathrm{~km}$ to the north, in the municipality of Oaxaca de Juárez (Figure 2; CONABIO 2010b).

The information reported here contributes to the knowledge of the current geographical distribution of two species that are key for conservation, in two districts that have been relegated in mammal research and which now could be essential for understanding the displacement of species. These data provide baseline information for planning biological corridors, which are required given the accelerated changes of land use across large areas of Mexico in general and of the State of Oaxaca in particular, forcing wildlife individuals to search for new habitats to thrive.

\section{Acknowledgments}

M. Martínez-Zagal and F. Toledo-Mendez kindly assisted in gathering record information, R. Velásquez-Reyes drafted Figure 2, F. A. Cervantes and Y. Hortelano added the jaguarundi specimen to the CNMA, and F. Botello added the photographs to the Colección de Fotocolectas Biológicas. C. Manrique provided a critical review of the manuscript. Compañía Minera Cuzcatlán and Instituto Politécnico Nacional of Mexico provided logistical support for this 
work. María Elena Sánchez-Salazar translated the manuscript into English.

\section{Literature cited}

Álvarez-Castañeda, S. T., and N. GonzÁlez-Ruiz. 2018. Spanish and English vernacular names of mammals of North America. Therya 9:73-84.

ARANDA, S., J. M. 2012. Manual para el rastreo de mamíferos silvestres de México. Comisión Nacional para el Conocimiento y Uso de la Biodiversidad. Ciudad de México, México.

Briones-Salas, M., and V. Sánchez-Cordero. 2004. Mamíferos. Pp. 423-477 in Biodiversidad de Oaxaca (García-Mendoza, A. J., M. de J. Ordóñez, y M. Briones-Salas, eds.) Instituto de Biología, Universidad Nacional Autónoma de México-Fondo Oaxaqueño para la Conservación de la Naturaleza-World Wildlife Fund. Oaxaca, México.

Briones-Salas M., M. C. Lavariega-Nolasco, M. Cortés-Marcial, A. G. Monroy-Gamboa, and C. A. Masés-García. 2016. Iniciativas de conservación para los mamíferos de Oaxaca, México. Pp. 329366 in Riqueza y Conservación de los Mamíferos en México a Nivel Estatal (Briones-Salas, M., Y. Hortelano-Moncada, G. Magaña-Cota, G. Sánchez-Rojas, and J. E. Sosa-Escalante, eds.). Instituto de Biología, Universidad Nacional Autónoma de México, Asociación Mexicana de Mastozoología A. C., and Universidad de Guanajuato. Ciudad de México, México.

Botello, F., P. Illoldi-Rangel, M. Linaje, and V. Sánchez-Cordero. 2006. Primer registro del tigrillo (Leopardus wiedii, Schinz 1821) y del gato montés (Lynx rufus, Kerr 1792) en la Reserva de la Biósfera de Tehuacán-Cuicatlán, Oaxaca, México. Acta Zoológica Mexicana (n. s.) 22:135-139.

Botello, F., E. Villaseñor, L. Guevara, Á. Mendez, A. Cortés, J. Iglesias, M. IzúCar, M. Luna, A. Martínez, AND J. M. Salazar. 2013. Registros notables del zorrillo manchado (Spilogale angustifrons) y del jaguarundi (Puma yagouaroundi) en la Reserva de la Biosfera de Tehuacán-Cuicatlán, Oaxaca, México. Revista Mexicana de Biodiversidad 84:713-717.

CINTA, M., C. C. 2007. Construcción y validación de un modelo de nicho ecológico para jaguar (Panthera onca) y puma (Puma concolor) en la Sierra Madre de Oaxaca, México. Tesis de Maestría en Ciencias en Conservación y Aprovechamiento de Recursos Naturales, CIIDIR Unidad Oaxaca, Instituto Politécnico Nacional. Oaxaca, México.

Cinta-Magallón, C. C., C. R. Bonilla-Ruz, I. Alarcón-D., and J. ArroyoCABrales. 2012. Dos nuevos registros de margay (Leopardus wiedii) en Oaxaca, México, con datos sobre hábitos alimentarios. Cuadernos de Investigación UNED 4:33-40.

Comisión Nacional para el Conocimiento y Uso de la Biodiversidad (ConABIO A). 2010. Herpailurus yagouaroundi (jaguarundi). Distribución conocida. Comisión Nacional para el Conocimiento y Uso de la Biodiversidad. http://www. conabio.gob.mx/ Consultado el 07 de abril 2018.

Comisión Nacional para el Conocimiento y Uso de la Biodiversidad (ConABIO B). 2010. Leopardus wiedii (tigrillo). Distribución conocida. Comisión Nacional para el Conocimiento y Uso de la Biodiversidad. http://www.conabio.gob.mx/Consultado el 07 de abril 2018.

Goodwin, G. G. 1969. Mammals from the state of Oaxaca, Mexico, in the American Museum of Natural History. Bulletin of the American Museum of Natural History 141:1-270.
HALL, E. R. 1981. Mammals of North America. John Wiley and Sons. New York, U. S. A.

Lavariega, M. C., N. Martín-Regalado, and R. M. Gómez-Ugalde. 2012. Mamíferos del centro-occidente de Oaxaca, México. Therya, 3:349-370.

Meraz, J., B. Lobato-Yañez, and B. González-Bravo. 2010. El Ocelote (Leopardus pardalis) y Tigrillo (Leopardus wiedii) en la costa de Oaxaca. Ciencia y Mar 14:53-55.

Monroy GarcíA, Y. 2009. Diversidad beta de la mastofauna terrestre del estado de Oaxaca, México. Tesis de Maestría en Ciencias en Conservación y Aprovechamiento de Recursos Naturales, CIIDIR Unidad Oaxaca, Instituto Politécnico Nacional. Oaxaca, México.

Pérez, I., G. 2008. Diversidad de mamíferos carnívoros terrestres en una selva mediana en el Distrito de Tuxtepec, Oaxaca. Tesis de Maestría en Ciencias en Conservación y Aprovechamiento de Recursos Naturales, CIIDIR Unidad Oaxaca, Instituto Politécnico Nacional. Oaxaca, México.

ReID, F. A. 1997. A field guide to the mammals of Central America and Southeast Mexico. Oxford University Press. New York, U. S. A.

Santos-Moreno, A. 2014. Los mamíferos del estado de Oaxaca. Revista Mexicana de Mastozoología Nueva época 4:18-32.

Secretaría de Medio Ambiente y Recursos Naturales (Semarnat). 2010. Norma Oficial Mexicana NOM-059-SEMARNAT-2010, Protección ambiental-Especies nativas de México de flora y fauna silvestres. Categoría de riesgo y especificaciones para su inclusión, exclusión o cambio. Lista de especies en riesgo. Secretaría de Medio Ambiente y Recursos Naturales. México. 30 de diciembre de 2010.

Villa, B., and F. Cervantes. 2003. Los mamíferos de México. Grupo Editorial Iberoamericana, México.

Associated editor: Jorge Servin Submitted: November 7, 2017; Reviewed: January 29, 2018; Accepted:August 18, 2018; Published on line: September 27, 2018. 
